\title{
Pengaruh Motivasi Kerja terhadap Kinerja Pegawai pada Produksi Baja Karbon Rendah
}

\author{
Stephanus Benedictus Bera Liwun ${ }^{1 *}$, Alvya Agasvyra Devania Putri ${ }^{2}$ \\ ${ }^{1,2}$ Program Studi Teknik Industri, Universitas Gunadarma, Depok, Indonesia \\ ('stephanusliwun@gmail.com)
}

\begin{abstract}
Abstrak - Kinerja pegawai merupakan salah satu indikator evaluasi untuk kenaikan atau penurunan jabatan. Kinerja yang tinggi juga bisa mendapatkan hasil yang tinggi, namun hal yang mendorongnya bisa berasal dari beberapa faktor. Bentuk motivasi kerja lainnya, motivasi kerja yang dirasakan pegawai dan menurunkan kinerja atau meningkatkan kinerja pegawai. Pegawai yang merasa puas dengan pekerjaan yang didapatkannya akan termotivasi untuk meningkatkan kinerjanya sehingga berdampak pada peningkatan kinerja perusahaan secara keseluruhan. Penelitian ini bertujuan untuk menganalisis pengaruh motivasi kerja terhadap kinerja pegawai. Pendekatan penelitian ini dilakukan dengan metode kuantitatif yang mengukur nilai dari motivasi kerja dan kinerja pegawai. Instrumen yang digunakan berupa kuesioner yang tersusun dalam skala likert. Analisis data dilakukan dengan uji regresi linier. Hasil dari penelitian ini adalah terdapat pengaruh dari motivasi kerja terhadap kinerja pegawai.
\end{abstract}

Kata kunci: baja karbon; kinerja pegawai; motivasi kerja; uji regresi

\section{PENDAHULUAN}

Sebuah industri dapat dikatakan sukses dan berhasil apabila karyawan yang bekerja dalam industri tersebut bekerja dengan baik sehingga dapat menunjang tujuan dari industri atau organisasi tersebut. Taticchi, Tonelli, dan Cagnozzo (2010) berpendapat bahwa untuk meningkatkan kinerja bisnis, pengukuran telah diakui sebagai elemen penting. Demikian pula untuk menjaga stabilitas dalam pengukuran kinerja, beberapa aspek telah diperhatikan. Striteska dan Spickova (2012) menyebutkan pengukuran kinerja sebagai proses pengukuran efektivitas dan efisiensi, serta produktvitas dibandingkan dengan apa yang telah dilakukan di masa lampau. Lebih lanjut Moullin (2007) menyatakan bahwa pengukuran kinerja dapat dirumuskan sebagai penilaian seberapa baik organisasi dikelola dan nilai yang disampaikannya kepada pemangku kepentingan. Pendapat ini diperkuat juga dengan penelitian Suprihati (2014) yang menunjukkan bahwa variabel motivasi memiliki pengaruh yang signifikan terhadap variabel kinerja pegawai sebesar $66 \%$, sedangkan sisanya (34 \%) dijelaskan oleh variabel lainnya yang tidak termasuk dalam model regresi seperti kepemimpinan, kepuasan kerja dan lain-lainnya. Penelitian Kiki (2015) juga menyatakan bahwa besarnya pengaruh langsung motivasi kerja terhadap kinerja adalah sebesar $26,68 \%$. Kinerja pegawai menjadi sangat penting sebab penurunan kinerja baik individu maupun kelompok dalam suatu perusahaan dapat memberikan dampak yang signifikan dalam suatu perusahaan, yang akan berdampak pada pencapaian tujuan organisasi. Banyak faktor yang dapat menurunkan kinerja karyawan, seperti praktik yang dibatasi oleh atasan dan juga lingkungan kerja fisik yang berkaitan dengan pencahayaan, suhu, kebisingan (Pinder, 1998).

Motivasi kerja menurut Robbin (2013) adalah suatu keinginan untuk melakukan sebagai kesediaan untuk mencurahkan tingkat komitmen yang tinggi terhadap tujuan organisasi, yang dikondisikan oleh kemampuan upaya pencapaian atau kebutuhan kelompok. Penelitian selanjutnya dilakukan Slamet (2011) menunjukkan bahwa motivasi kerja berpengaruh signifikan terhadap kinerja karyawan dengan nilai statistik sebesar 4,293. Hal ini juga sejalan dengan penelitian Ririvega (2013) yang menunjukkan nilai koefisien regresi motivasi sebesar 0,550 yang berarti motivasi yang meningkat akan meningkatkan kinerja pegawai.

Kinerja pegawai memiliki indikator bahwa pegawai dapat bekerja dengan baik sesuai dengan prosedur dari perusahaan. Kinerja karyawan yang ideal ini dapat terealisasi seandainya didukung oleh motivasi kerja yang baik dalam bekerja. Selain itu, dapat juga dikemukakan bahwa motivasi kerja berbanding lurus dengan kinerja pegawai, sehingga jika motivasi kerja tinggi maka kinerja pegawai juga akan tinggi. Pada beberapa kasus motivasi kerja dapat memberikan dampak positif dan signifikan terhadap kinerja pegawai. Contohnya: pemberian bonus, pemberian tunjangan, dan penghargaan bagi karyawan yang berprestasi maupun mencapai target yang ditetapkan oleh perusahaan (Arnawa \& Heryanda, 2021). Tujuan penelitian adalah untuk menguji pengaruh motivasi kerja terhadap kinerja pegawai. 


\section{STUDI LITERATUR}

Robbins dan Judge (2013) menyatakan bahwa kinerja adalah suatu prestasi yang dicapai oleh pegawai dalam pekerjaannya menurut kriteria tertentu yang berlaku pada suatu pekerjaan. Kinerja dapat dinyatakan juga sebagai hasil dari keberhasilan seseorang terhadap pekerjaan yang dilakukannya sesuai dengan tanggung jawab yang diberikan. Hasil layanan ini biasanya dievaluasi dalam jangka waktu tertentu sesuai dengan kebutuhan bisnis.

Variabel lain yang diteliti adalah motivasi kerja. Herzberg (dalam Robbins dan Judge, 2013) menyatakan bahwa motivasi kerja adalah sikap seseorang terhadap pekerjaannya agar tercipta rasa puas dalam kinerjanya. Teori yang dikembangkan oleh Herzberg ini dikenal dengan teori dua faktor, yaitu Faktor motivasional dan faktor hygiene atau pemeliharaan. Faktor motivasional merupakan pendorong keberhasilan yang bersifat intrinsik yaitu berasal dari dalam diri seseorang, sedangkan faktor hygiene atau pemeliharaan adalah faktorfaktor yang sifatnya ekstrinsik yang berasal dari luar diri seseorang. Berdasarkan pernyataan tersebut dapat menyimpulkan bahwa motivasi kerja adalah motivasi individu yang mengarah pada tujuan organisasi.

Beberapa penelitian terbaru yang berhubungan dengan motivasi kerja dan kinerja karyawan dapat disajikan pada Tabel 1.

Tabel 1

Penelitian terkait motivasi kerja dan kinerja karyawan

\begin{tabular}{|c|c|c|}
\hline Penulis & Variabel & Hasil \\
\hline Lantara (2018) & $\begin{array}{l}\text { Motivasi kerja* } \\
\text { Kinerja karyawan* } \\
\text { Kepuasan kerja (intervining } \\
\text { variable) }\end{array}$ & $\begin{array}{l}\text { Ada pengaruh tidak langsung antara motivasi kerja } \\
\text { terhadap kinerja karyawan melalui kepuasan kerja yang } \\
\text { bersifat signifikan }\end{array}$ \\
\hline $\begin{array}{l}\text { Dunggio dan Basri } \\
(2019)\end{array}$ & $\begin{array}{l}\text { Sistem kerja kontrak } \\
\text { Motivasi kerja* } \\
\text { Kinerja karyawan* }\end{array}$ & $\begin{array}{l}\text { Motivasi kerja yang tinggi akan meningkatkan kinerja } \\
\text { karyawan }\end{array}$ \\
\hline $\begin{array}{l}\text { Pratiwi dan Bagia } \\
(2021)\end{array}$ & $\begin{array}{l}\text { Motivasi kerja* } \\
\text { Kemampuan kerja } \\
\text { Kinerja pegawai* }\end{array}$ & $\begin{array}{l}\text { Motivasi kerja memberi pengaruh positif pada kinerja } \\
\text { pegawai. }\end{array}$ \\
\hline $\begin{array}{l}\text { Kristanti dan Lestari } \\
(2019)\end{array}$ & $\begin{array}{l}\text { Disiplin kerja } \\
\text { Motivasi kerja* } \\
\text { Kinerja karyawan* }\end{array}$ & $\begin{array}{l}\text { Ada pengaruh positif dan signifikan motivasi kerja } \\
\text { terhadap kinerja karyawan. } \\
\text { Ada pengaruh positif dan signifikan dari disiplin kerja } \\
\text { dan motivasi kerja secara bersama-sama terhadap kinerja } \\
\text { karaywan. }\end{array}$ \\
\hline $\begin{array}{l}\text { Damayanti dan } \\
\text { Trianasari } \\
(2020)\end{array}$ & $\begin{array}{l}\text { Kemampuan kerja } \\
\text { Motivasi kerja* } \\
\text { Kinerja karyawan* }\end{array}$ & $\begin{array}{l}\text { Motivasi berpengaruh terhadap kinerja karyawan. } \\
\text { Kemampuan kerja dan motivasi kerja berpengaruh } \\
\text { terhadap kinerja karyawan }\end{array}$ \\
\hline Tamim (2020) & $\begin{array}{l}\text { Lingkungan kerja } \\
\text { Motivasi kerja* } \\
\text { Kinerja karyawan* }\end{array}$ & $\begin{array}{l}\text { Motivasi kerja secara persial berpengaruh terhadap } \\
\text { Kinerja karyawan. }\end{array}$ \\
\hline
\end{tabular}

\section{METODOLOGI}

Penelitian ini melibatkan dua jenis variabel, yaitu variabel bebas dan variabel terikat. Variabel bebas (X) pada penelitian ini adalah motivasi kerja dan variabel terikat $(\mathrm{Y})$ pada penelitian ini adalah kinerja karyawan. Subjek pada penelitian ini terdiri atas 46 subjek penelitian antara beberapa divisi. Instrumen kinerja karyawan diadaptasi menurut penelitian Syalman (2017) dengan nilai reliabilitas sebesar 0,738. Instrumen motivasi kerja diadaptasi dari penelitian Tampubolon (2007) dengan nilai reliabilitas sebesar 0,829. Setiap instrumen terdiri atas beberapa pernyataan serta setiap pernyataan terdiri atas empat pilihan jawaban yang bersifat dikotomi yaitu sangat setuju, setuju, tidak setuju, dan sangat tidak setuju. Setiap pilihan jawaban memiliki nilai yaitu 4, 3,2 , dan 1 . Semua pernyataan akan sama dalam pemberian nilainya karena semua pernyataan memiliki sifat positif. Misalnya pada pernyataan pertama seorang responden menjawab setuju maka nilai pada pernyataan tersebut adalah 3. Kemudian semua nilai dari jawaban responden dijumlahkan untuk satu instrument yang mengukur satu variabel. 


\section{A. Operasionalisasi Variabel-variabel}

Kinerja pegawai didefinisikan sebagai luaran dari kerja berupa kualitas juga kuantitas yang dicapai menurut seseorang pada melakukan suatu tugas yang merupakan tanggung jawab yang telah diberikan dirinya. Motivasi kerja dapat didefinisikan sebagai suatu dorongan yang mensugesti seseorang untuk melakukan sesuatu supaya mencapai hasil dan tujuan yang telah ditentukan. Kuesioner variabel motivasi kerja dan kinerja pegawai memakai skala likert dengan empat pilihan jawaban, skala likert dipakai buat untuk mengukur sikap, pendapat, dan persepsi individu.

\section{B. Instrumen Pengumpulan Data}

Instrumen penelitian adalah alat bantu yang digunakan oleh peneliti untuk memudahkan dalam pengukuran variabel. Instrumen dalam penelitian ini menggunakan kuesioner, yaitu alat pengumpulan data primer dengan menggunakan seperangkat daftar pernyataan. Variabel yang digunakan dalam kuesioner ini adalah variabel kinerja pegawai dan motivasi kerja.

1. Kinerja pegawai

Penggunaan skala kinerja pegawai berasal dari sumber penelitian Syalman (2017) dengan subjek penelitian ini karyawan photo copy di wilayah Yogyakarta. Hasil pencarian reliabilitas penelitian sebesar 0,738.

Tabel 2

Distribusi item kinerja karyawan

\begin{tabular}{|c|c|c|c|c|}
\hline Dimensi & Indikator & $\begin{array}{c}\text { Nomor Aitem } \\
\text { Favorable }\end{array}$ & $\begin{array}{c}\text { Nomor Aitem } \\
\text { Unfavorable }\end{array}$ & Total \\
\hline Kualitas & $\begin{array}{l}\text { Kualitas kerja diukur dari persepsi } \\
\text { karyawan terhadap kualitas pekerjaan } \\
\text { yang dihasilkan serta kesempurnaan } \\
\text { tugas terhadap keterampilan dan } \\
\text { kemampuan karyawan }\end{array}$ & 1,2 & & 2 \\
\hline Kuantitas & $\begin{array}{l}\text { Jumlah yang dihasilkan dinyatakan } \\
\text { dalam istilah seperti jumlah unit, } \\
\text { jumlah siklus aktivitas yang } \\
\text { diselesaikan }\end{array}$ & 3,4 & & 2 \\
\hline $\begin{array}{l}\text { Ketepatan } \\
\text { waktu }\end{array}$ & $\begin{array}{l}\text { Tingkat aktivitas diselesaikan pada } \\
\text { awal waktu yang dinyatakan, dilihat } \\
\text { dari sudut koordinasi dengan hasil } \\
\text { output serta memaksimalkan waktu } \\
\text { yang tersedia untuk aktivitas lain }\end{array}$ & $5,6,7,8$ & & 4 \\
\hline $\begin{array}{l}\text { Komitmen } \\
\text { kerja }\end{array}$ & $\begin{array}{l}\text { Suatu tingkat dimana karyawan } \\
\text { mempunyai komitmen kerja dengan } \\
\text { instansi dan tanggung jawab karyawan } \\
\text { terhadap kantor }\end{array}$ & 9,10 & & 2 \\
\hline
\end{tabular}

2. Motivasi

Penggunaan skala motivasi kerja berasal dari sumber penelitian Tampubolon (2007) dengan subjek pegawai yang bekerja di organisasi yang telah menerapkan SNI 19-9001-2001. Hasil pencarian reliabilitas penelitian dengan koefisien Cronbach Alpha sebesar 0,781. 
Tabel 3

Distribusi item motivasi kerja

\begin{tabular}{|c|c|c|c|c|}
\hline Dimensi & Indikator & $\begin{array}{c}\text { Nomor } \\
\text { Aitem } \\
\text { Favorable }\end{array}$ & $\begin{array}{l}\text { Nomor Aitem } \\
\text { Unfavorable }\end{array}$ & Total \\
\hline $\begin{array}{l}\text { Kebutuhan } \\
\text { Fisiologis }\end{array}$ & $\begin{array}{l}\text { Kebutuhan makan, minum, dan } \\
\text { mendapat tempat tinggal. }\end{array}$ & $1,2,3,19$ & & 4 \\
\hline $\begin{array}{l}\text { Kebutuhan } \\
\text { Keselamatan } \\
\text { dan Keamanan }\end{array}$ & $\begin{array}{l}\text { Kebutuhan akan kebebasan dari } \\
\text { ancaman, seperti aman dari } \\
\text { ancaman lingkungan (penjahat } \\
\text { dan gangguan lingkungan } \\
\text { lainnya). }\end{array}$ & 4,5 & & 2 \\
\hline $\begin{array}{l}\text { Kebutuhan Rasa } \\
\text { Memiliki Cinta }\end{array}$ & $\begin{array}{l}\text { Kebutuhan akan teman, afiliasi, } \\
\text { interaksi, mencintai dan } \\
\text { dicintai. }\end{array}$ & $6,17,20$ & & 3 \\
\hline $\begin{array}{l}\text { Kebutuhan } \\
\text { Akan } \\
\text { Penghargaan }\end{array}$ & $\begin{array}{l}\text { Kebutuhan akan penghargaan } \\
\text { diri dan penghargaan orang } \\
\text { lain. }\end{array}$ & $8,9,12,13$ & & 4 \\
\hline $\begin{array}{l}\text { Kebutuhan } \\
\text { Akan Realisasi } \\
\text { Diri }\end{array}$ & $\begin{array}{l}\text { Kebutuhan untuk memenuhi } \\
\text { sendiri dengan penggunaan } \\
\text { kemampuan maksimum, } \\
\text { melalui keterampilan dan } \\
\text { potensi yang ada. }\end{array}$ & $\begin{array}{c}7,10,11,14,1 \\
5,16,18\end{array}$ & & 7 \\
\hline
\end{tabular}

\section{Validitas dan Reliabilitas Instrumen}

Hasil perhitungan korelasi akan diperoleh koefisien korelasi yang memungkinkan untuk mengukur tingkat validitas suatu item dan untuk menentukan suatu item layak digunakan atau tidak. Penentuan layak atau tidaknya biasanya dilakukan uji signifikansi koefisien korelasi pada taraf signifikansi 0,3 . Hal ini berarti suatu item dianggap valid jika berkorelasi signifikan dengan skor total.

Mengukur reliabilitas instrumen dalam penelitian ini dengan menyebarkan kuesioner kepada responden. Beberapa praktisi berpendapat bahwa suatu pernyataan dikatakan valid jika memiliki nilai Cronbach's Alpha lebih besar dari 0,6 .

Tabel 4

Hasil uji reliabilitas variabel kinerja

\begin{tabular}{cccc}
\hline No. & Variabel & R alpha & Kriteria \\
\hline 1. & Kinerja & 0,802 & Reliable \\
2. & Motivasi kerja & 0,747 & Reliable \\
\hline
\end{tabular}

Uji asumsi klasik digunakan sebagai syarat dalam menggunakan model regresi agar hasil regresi yang diperoleh merupakan estimasi yang tepat.

\section{HASIL DAN DISKUSI}

Subjek dalam penelitian ini terdiri dari 46 subjek penelitian yang berasal dari berbagai divisi kerja, yaitu Plant Engineering, K3, Logistik, Maintenance, P4, Produksi, dan Laboratorium. Profil subjek penelitian meliputi usia, jenis kelamin, posisi, lama bekerja, dan jenjang pendidikan. Profil subjek dapat disajikan pada Tabel 5. 
Tabel 5

Deskripsi subjek penelitian

\begin{tabular}{|c|c|c|c|c|c|}
\hline \multirow[t]{2}{*}{ Kualifikasi } & \multirow[t]{2}{*}{ Klasifikasi } & \multirow{2}{*}{$\begin{array}{l}\text { Jumlah } \\
\text { (Orang) }\end{array}$} & \multirow{2}{*}{$\begin{array}{c}\text { Persentase } \\
(\%)\end{array}$} & \multicolumn{2}{|c|}{ Rata-rata } \\
\hline & & & & $\begin{array}{c}\text { Motivasi } \\
\text { Kerja }\end{array}$ & $\begin{array}{c}\text { Kinerja } \\
\text { Karyawan }\end{array}$ \\
\hline \multirow[t]{6}{*}{$\begin{array}{c}\text { Usia } \\
\text { (tahun) }\end{array}$} & $\begin{array}{l}19-24 \\
25-30\end{array}$ & $\begin{array}{c}8 \\
13\end{array}$ & $\begin{array}{l}17.391 \\
28.260\end{array}$ & $\begin{array}{c}69,125 \\
65\end{array}$ & $\begin{array}{c}33.25 \\
34\end{array}$ \\
\hline & $31-36$ & 3 & 6,5217 & 65,667 & 35,334 \\
\hline & $37-42$ & 6 & 13,043 & 67,834 & 33,834 \\
\hline & $43-48$ & 2 & 4,347 & 62,5 & 30 \\
\hline & $49-54$ & 8 & 17,391 & 64,75 & 32,5 \\
\hline & $55-60$ & 6 & 13,043 & 64,571 & 34,714 \\
\hline \multirow[t]{2}{*}{ Jenis Kelamin } & Pria & 44 & 95,652 & 65,886 & 33,522 \\
\hline & Wanita & 2 & 4,348 & 68,667 & 31,667 \\
\hline \multirow[t]{5}{*}{ Posisi/ Jabatan } & $\begin{array}{c}\text { Kepala } \\
\text { Staf }\end{array}$ & $\begin{array}{l}16 \\
26\end{array}$ & $\begin{array}{l}34,782 \\
56,521\end{array}$ & $\begin{array}{l}64,562 \\
66,961\end{array}$ & $\begin{array}{c}33,562 \\
33,5\end{array}$ \\
\hline & $\begin{array}{l}\text { Electrical } \\
\text { Engineer }\end{array}$ & 1 & 2,174 & 64 & 37 \\
\hline & Barcoder & 1 & 2,174 & 67 & 35 \\
\hline & $\begin{array}{c}\text { Operator } \\
\text { Crane }\end{array}$ & 1 & 2,174 & 65 & 30 \\
\hline & $\begin{array}{l}\text { Operator } \\
\text { Forklift }\end{array}$ & 1 & 2,174 & 64 & 30 \\
\hline \multirow[t]{4}{*}{ Lama Bekerja (tahun) } & $\begin{array}{c}<1 \\
1-10\end{array}$ & $\begin{array}{c}1 \\
27\end{array}$ & $\begin{array}{c}2,174 \\
58,695\end{array}$ & $\begin{array}{c}66 \\
66,518\end{array}$ & $\begin{array}{c}30 \\
33,962\end{array}$ \\
\hline & $11-20$ & 4 & 8,695 & 66,25 & 32,5 \\
\hline & $21-30$ & 6 & 13,043 & 64,834 & 33,334 \\
\hline & $>30$ & 8 & 17,391 & 64,75 & 32,875 \\
\hline \multirow[t]{5}{*}{ Pendidikan Terakhir } & SMA & 29 & 63,043 & 66,344 & 33,413 \\
\hline & Diploma III & 2 & 4,347 & 67,334 & 32 \\
\hline & Sarjana & 14 & 30,434 & 66,571 & 33,286 \\
\hline & Pasca Sarjana & 1 & 2,174 & 68 & 30,5 \\
\hline & & 46 & $100 \%$ & 65,956 & 33,478 \\
\hline
\end{tabular}

\section{A. Uji Normalitas}

Uji normalitas berguna untuk memeriksa apakah dalam model regresi, variabel terikat dan variabel bebas berdistribusi normal atau tidak. Uji normalitas dalam penelitian ini menggunakan distribusi pada grafik P-P plot. Berikut ini hasil uji normalitas menggunakan grafik P-P Plot menggunakan bantuan perangkat lunak SPSS versi 16:

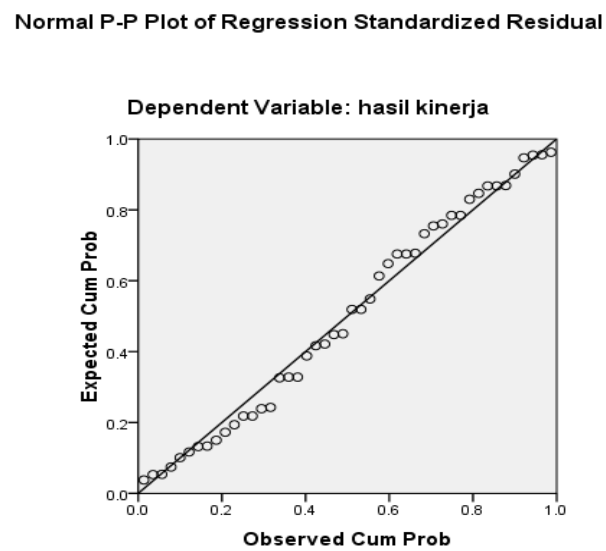

Gambar 1. Grafik P-Plot

Berdasarkan Gambar 1 terlihat bahwa data memanjang di sekitar garis diagonal dan mengikuti arah garis diagonal pada grafik histogram, hal ini menunjukkan bahwa pola sebarannya normal. Dengan demikian dapat disimpulkan bahwa berdasarkan grafik P-P plot, model regresi memenuhi asumsi normalitas. 


\section{B. Uji Linieritas}

Uji linieritas bertujuan untuk memeriksa dalam model regresi ada ketidaksamaan variasi dari residu dari satu pengamatan ke pengamatan yang lain. Cara untuk mengetahui ada linieritas atau tidak adalah dengan melihat Grafik Plot antara nilai prediksi variabel terikat yaitu ZPRED dengan linieritas residual SRESID yaitu jika tidak ada pola yang jelas, serta titik-titik tersebar di atas dan di bawah angka 0 pada sumbu $Y$.

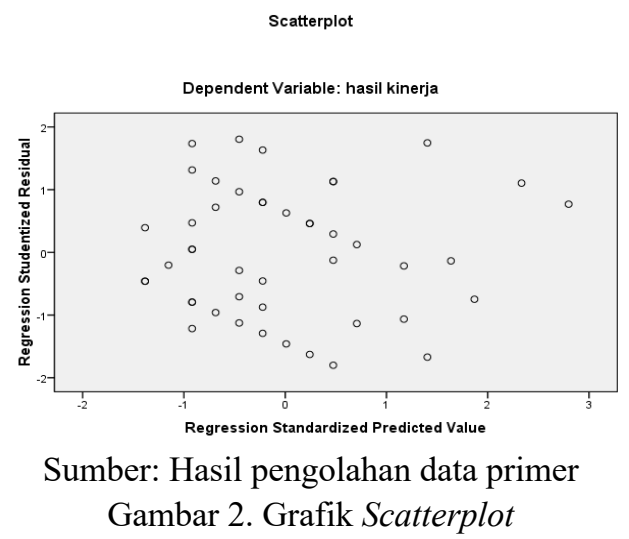

Berdasarkan Gambar 2, terlihat bahwa tidak ada pola yang jelas dan titik-titik tersebut memanjang di atas dan di bawah angka 0 pada sumbu Y. Hal ini menunjukkan bahwa data dalam penelitian ini tidak terjadi linieritas.

\section{Uji Multikolinieritas}

Uji multikolinieritas berguna untuk memeriksa apakah model regresi ditemukan adanya korelasi antara variabel bebas dalam model regresi. Variabel bebas, jika nilai Tolerance lebih besar dari 0,10 dan nilai VIF lebih kecil dari 10, maka data tersebut bebas dari gejala multikolinieritas.

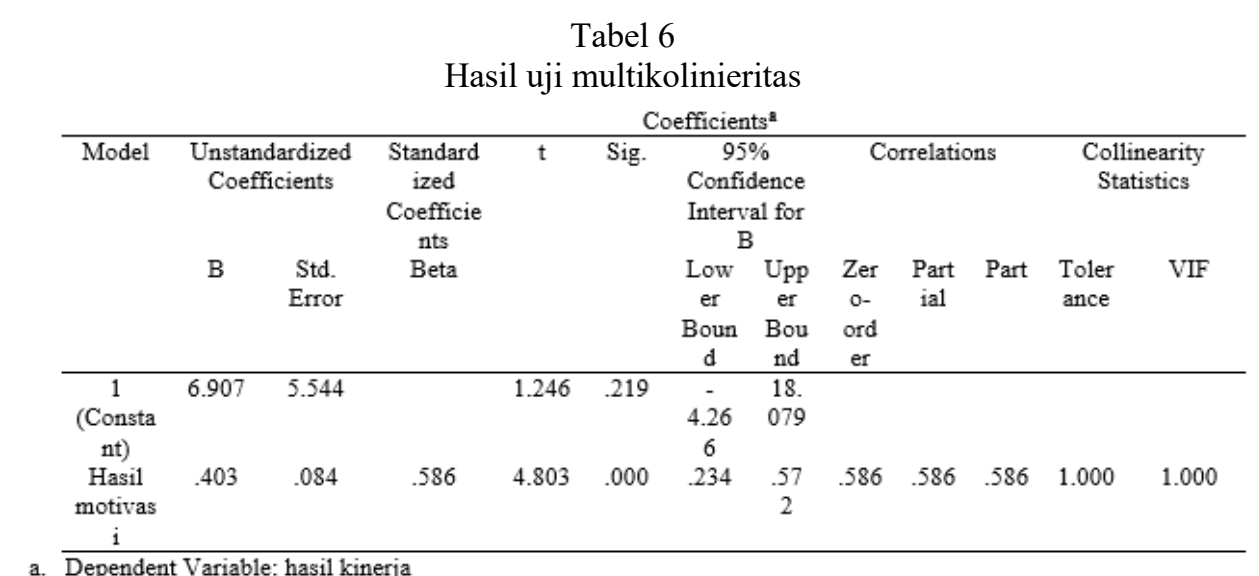

Tabel 6, hasil perhitungan nilai Tolerance tidak ada variabel bebas yang memiliki nilai Tolerance kurang dari 0,10 dengan nilai Tolerance variabel bebas sebesar 1,000. Sedangkan, hasil perhitungan nilai Variance Inflation Factor (VIF) juga menunjukkan hal yang sama, yaitu tidak adanya nilai VIF dari variabel bebas yang memiliki nilai VIF lebih besar dari 0,10 dengan nilai VIF variabel sebesar 1,000. Dalam merujuk pada hasil perhitungan nilai Tolerance dan VIF dapat disimpulkan bahwa tidak ada multikolinieritas antar variabel bebas dalam model regresi. Luaran regresi linier dengan menggunakan luaran SPSS 16 akan menampilkan hasil ringkasan model. 
Tabel 7

Ringkasan model

\begin{tabular}{|c|c|c|c|c|c|c|c|c|c|c|}
\hline \multirow[t]{2}{*}{ Model } & \multirow[t]{2}{*}{$\mathrm{R}$} & \multirow{2}{*}{$\begin{array}{c}\text { R } \\
\text { Square }\end{array}$} & \multirow{2}{*}{$\begin{array}{c}\text { Adjusted } \\
\text { R } \\
\text { Square }\end{array}$} & \multirow{2}{*}{$\begin{array}{c}\text { Std. } \\
\text { Error of } \\
\text { Estimate }\end{array}$} & \multicolumn{5}{|c|}{ Change Statistic } & \multirow{2}{*}{$\begin{array}{l}\text { Durbin } \\
\text { Watson }\end{array}$} \\
\hline & & & & & $\begin{array}{l}\text { R } \\
\text { Square } \\
\text { Change }\end{array}$ & $\begin{array}{c}\text { F } \\
\text { Change }\end{array}$ & df1 & $\mathrm{df} 2$ & $\begin{array}{l}\text { Sig. F } \\
\text { Change }\end{array}$ & \\
\hline 1 & $.586^{\mathrm{a}}$ & .344 & .329 & 2.42212 & .344 & 23.070 & 1 & 44 & .000 & 2.087 \\
\hline
\end{tabular}

a. Predictors: (Constant), hasil motivasi

b. Dependent Variable: hasil kinerja

Tabel 7, menunjukkan nilai $\mathrm{R}$ yang merupakan simbol dari nilai koefisien korelasi, pada contoh di atas nilai korelasi adalah 0,586. Nilai ini dapat diartikan sebagai hubungan antara kedua variabel penelitian baik dalam kategori cukup. Variabel bebas dan variabel terikat. Nilai KD yang diperoleh sebesar $34,4 \%$ yang dapat diartikan sebagai variabel bebas X memberikan kontribusi pengaruh sebesar 34,4\% terhadap variabel Y dan $65,6 \%$ lainnya dipengaruhi oleh faktor-faktor lain di luar variabel X.

Tabel 8

Analysis of Variant (ANOVA)

\begin{tabular}{|c|c|c|c|c|c|c|}
\hline \multicolumn{7}{|c|}{ ANOVA $^{b}$} \\
\hline Model & & Sum of Squares & df & Mean Square & $\mathrm{F}$ & Sig. \\
\hline \multirow[t]{3}{*}{1} & Regression & 135.346 & 1 & 135.346 & 23.070 & $.000^{\mathrm{a}}$ \\
\hline & Residual & 258.132 & 44 & 5.867 & & \\
\hline & Total & 393.478 & 45 & & & \\
\hline \multicolumn{7}{|c|}{ a. Predictors: (Constant), hasil motivasi } \\
\hline \multicolumn{7}{|c|}{ b. Dependent Variable: hasil kinerja } \\
\hline
\end{tabular}

Pada Tabel 8 digunakan untuk menentukan tingkat signifikansi atau linieritas dari regresi. Kriteria dapat ditentukan berdasarkan uji F atau uji nilai signifikansi (Sig.). Cara termudah adalah uji Sig., dengan ketentuan, jika Nilai Sig. $<0,05$, maka model regresinya linier, dan berlaku sebaliknya. Berdasarkan tabel 8, diperoleh nilai Sig. $=0,000$ yang berarti $<$ kriteria signifikan $(0,05)$, sehingga model persamaan regresi berdasarkan data penelitian adalah signifikan, yang berarti model regresi linier memenuhi kriteria linieritas. Nilai $\mathrm{F}$ pada tabel di atas adalah 23,070. Angka ini merupakan nilai F hitung, yang kemudian dibandingkan dengan nilai pada table $\mathrm{F}$. Rumus untuk mencari $\mathrm{F}$ tabel adalah $\mathrm{F}=(0,05 ; 1 ; 45)(\mathrm{F}=\alpha ; \mathrm{k} ; \mathrm{n}-\mathrm{k})$ di mana $\mathrm{k}$ adalah jumlah variabel bebas dan $\mathrm{n}$ adalah jumlah responden, maka didapatkan hasil $\mathrm{f}$ tabel sebesar 4,06. Nilai $\mathrm{F}$ hitung lebih besar dari $\mathrm{F}$ tabel sehingga disimpulkan bahwa terdapat pengaruh yang signifikan antara motivasi kerja $(\mathrm{X})$ secara simultan terhadap kinerja karyawan (Y) dan sebaliknya.

Tabel 9

Koefisien

\begin{tabular}{|c|c|c|c|c|c|c|c|c|c|c|c|c|}
\hline \multirow[t]{2}{*}{ Model } & \multicolumn{2}{|c|}{$\begin{array}{l}\text { Unstandardized } \\
\text { Coefficients }\end{array}$} & \multirow{2}{*}{$\begin{array}{c}\text { Standardized } \\
\text { Coefficients } \\
\text { Beta }\end{array}$} & \multirow[t]{2}{*}{$\mathrm{t}$} & \multirow[t]{2}{*}{ Sig. } & \multicolumn{2}{|c|}{$\begin{array}{c}95 \% \\
\text { Confidence } \\
\text { Interval for B }\end{array}$} & \multicolumn{3}{|c|}{ Correlations } & \multicolumn{2}{|c|}{$\begin{array}{l}\text { Collinearity } \\
\text { Statistics }\end{array}$} \\
\hline & B & $\begin{array}{l}\text { Std. } \\
\text { Error }\end{array}$ & & & & $\begin{array}{l}\text { Lower } \\
\text { Bound }\end{array}$ & $\begin{array}{l}\text { Upper } \\
\text { Bound }\end{array}$ & $\begin{array}{l}\text { Zero- } \\
\text { order }\end{array}$ & $\begin{array}{c}\text { Part } \\
\text { ial }\end{array}$ & Part & $\begin{array}{l}\text { Toler } \\
\text {-ance }\end{array}$ & VIF \\
\hline 1 (Constant) & 6.907 & 5.544 & & 1.246 & .219 & -4.266 & 18.079 & & & & & \\
\hline $\begin{array}{c}\text { Hasil } \\
\text { motivasi }\end{array}$ & .403 & .084 & .586 & 4.803 & .000 & .234 & .572 & .586 & .586 & .586 & 1.000 & 1.000 \\
\hline
\end{tabular}

Tabel 9 menginformasikan model persamaan regresi yang diperoleh dengan koefisien konstanta dan koefisien variabel yang ada di kolom Unstandardized Coefficients B. Persamaan regresi dari model ini Y = $6.907+0.403 \mathrm{X}$. Artinya jika variabel motivasi kerja naik satu satuan, maka variabel kinerja pegawai akan meningkat sebesar $4,03 \%$.

Pengaruh yang diberikan oleh variabel bebas adalah positif, dalam arti semakin besar motivasi kerja maka kinerja pegawai yang dihasilkan akan semakin tinggi dan begitu pula sebaliknya semakin rendah motivasi kerja seorang karyawan maka semakin rendah pula kinerja karyawan yang dihasilkan. Indikator dari motivasi kerja yang mempengaruhi kinerja pegawai adalah kebutuhan akan penghargaan diri dan penghargaan orang lain. Selain itu juga, kebutuhan untuk memenuhi diri sendiri dengan penggunaan kemampuan maksimum 
melalui keterampilan dan potensi yang ada merupakan pengaruh utama dalam penelitian ini.

Pengolahan yang telah dilakukan menunjukkan bahwa nilai f hitung tersebut lebih besar dari f tabel sebesar 4,06, yang berarti dalam penelitian ini akan menerima Ha dan menolak Ho. Pengujian ini secara statistik menunjukkan bahwa motivasi kerja berpengaruh positif terhadap kinerja karyawan. Artinya bahwa ada pengaruh antara variabel motivasi kerja terhadap kinerja pegawai. Hasil ini juga ditunjukkan oleh Riyadi (2011) yang menunjukkan bahwa motivasi kerja berpengaruh signifikan terhadap kinerja pegawai. Penilaian kinerja adalah alat yang berguna tidak hanya untuk mengevaluasi pekerjaan pegawai, tetapi juga untuk mengembangkan dan memotivasi kalangan karyawan. Isu-isu sesuai dengan bidang kegiatannya semua layak untuk dinilai.

Hasil yang dikemukakan oleh Zameer dan Ali (2014) menunjukkan bahwa sumber daya manusia merupakan asset terpenting atau asset yang paling berharga dari suatu perusahaan yang tidak dapat digantikan. Perusahaan harus mampu memotivasi karyawan untuk bekerja dengan baik dan mencapai tujuan bisnis. Robescu dan Iancu, (2016), menegaskan bahwa motivasi manusia dalam suatu organisasi akan membawa tambahan kinerja bagi manajer yang berharap dapat mencapai tujuan organisasi. Namun, motivasi dan kinerja tidak dapat diperlakukan sebagai fenomena yang setara. Menyelesaikan pekerjaan secara efektif tidak hanya berasal dari motivasi, tetapi juga dari kinerja dan promosi sesegera mungkin.

\section{KESIMPULAN}

Hasil analisis data dan pengujian hipotesis dapat disimpulkan bahwa terdapat pengaruh dari motivasi kerja terhadap kinerja karyawan. Hal ini membuktikan bahwa variabel bebas berpengaruh terhadap variabel terikat. Pada penelitian selanjutnya dapat ditambahkan beberapa variabel yang mungkin mempengaruhi kinerja pegawai seperti budaya organisasi, keterlibatan kerja, komitmen organisasi, dan kegembiraan di tempat kerja.

\section{DAFTAR PUSTAKA}

Arnawa, I. M. P. \& Heryanda, K. K. (2021). Pengaruh komunikasi dan motivasi terhadap kinerja karyawan PT BPR Padma, Prospek: Jurnal Manajemen dan Bisnis, 3(1), 56-64.

Damayanti, D. M. C. B. \& Trianasari. (2020). Kemampuan kerja,, motivasi kerja, dan kinerja karyawan PT Delta Satria Dewata, Prospek: Jurnal Manajemen dan Bisnis, 2 (2), 185-193.

Dunggio, M. \& Basri, S. (2019). Pengaruh sistem kerja kontrak dan motivasi kerja terhadap kinerja karyawan pada perusahaan erha clinic, Kinerja, 16(2), 166-174.

Kristanti, D. \& Lestari, R. (2019). Pengaruh disiplin kerja karyawan dan motivasi terhadap kinerja karyawan bagian produksi studi di UD Pratama Karya Kota Kediri, Jurnal Nusamba, 4(2), 107-116.

Lantara, I Wayan Arya. (2018). Pengaruh motivasi kerja terhadap kinerja karaywan dengan kepuasan kerja sebagai variabel intervening di PT. Indonesia Tourism Development Corporation (ITDC), Jurnal Pendidikan Ekonomi Undiksha, 10(1), 146-155.

Mathis \& Jackson. (2001). Human Resource Management (Manajemen Sumber Daya Manusia). Jakarta: Salemba Empat.

Moullin, M. (2007). Perfomance measurement definitions Linking performance measurement and organisational excellence, International Journal of Health Care Assurance, 20(3), 181-183.

Pinder, C. C. (1998). Work motivation organizational behavior. Upper Saddle River, Prentice Hall, New Jersey.

Pratiwi, N. M. D. D., \& Bagia, I W. (2021). Motivasi kerja dan kemampuan kerja mempengaruhi kinerja pegawai pada PDAM Tirta Amertha Jati Kabupaten Jembrana, Prospek: Jurnal Manajemen dan Bisnis, $3(1), 22-28$.

Riyadi, S. (2011). Pengaruh kompensasi finansial, gaya kepemimpinan, dan motivasi kerja terhadap kinerja karyawan pada perusahaan manufaktur di Jawa Timur. Jurnal Manajemen dan Kewirausahaan, 13(1), 40-45.

Robescu. O. \& Iancu, A. (2016). The effect of motivation on employees perfoemance in organizations. Valahian Journal of Economic Studies. 0(0).

Robbins \& Judge. (2013). Perilaku Organisasi. Jakarta: Salemba Empat. 
Striteska, M. \& Spickova, M. (2012). Review and comparison of performance measurement systems. Journal of Organizational Management Studies. 2012, 1-13.

Tamim, M. A. (2020). Pengaruh lingkungan kerja dan motivasi kerja terhadap kinerja karyawan PDAM Lamongan, Jurnal Ekonomi Mahasiswa, 1-5.

Tampubolon, B. D. (2007). Pengaruh Gaya Kepemimpinan, Motivasi Kerja, Komitmen Organisasi terhadap Kepuasan Kerja dan Kinerja Pegawai. Jurnal Standardisasi. 9(3), 106-115.

Taticchi, P., Tonelli, F., \& Cagnozzo, L. (2010), Performance measurement and management: A literature review and a research agenda. Measuring Business Excellence, 14(1), 4-18.

Zameer \& Ali. (2004). The impact of the motivation on the employee's performance in beverage industri of Pakistan. International Journal of Academic Research in Accounting, Finance and Management Sciences, 4(1), 293-298. 